International Journal of

Environmental Research and

Public Health

ISSN 1660-4601

www.mdpi.com/journal/ijerph

Article

\title{
Radon Exposure Assessment and Relative Effective Dose Estimation to Inhabitants of Puglia Region, South Italy
}

\author{
Maria Quarto ${ }^{1,2, *}$, Mariagabriella Pugliese ${ }^{1,2}$, Giuseppe La Verde ${ }^{1}$, Filomena Loffredo ${ }^{2}$ and \\ Vincenzo Roca ${ }^{1,2}$
}

1 Dipartimento di Fisica, Università di Napoli Federico II, Naples 80126, Italy;

E-Mails: pugliese@na.infn.it (M.P.); giuseppelaverde@live.it (G.L.V.); roca@na.infn.it (V.R.)

2 Istituto Nazionale di Fisica Nucleare (INFN), Sezione di Napoli, Naples, 80126, Italy;

E-Mail: filomena.loffredo@unina.it

* Author to whom correspondence should be addressed; E-Mail: maria.quarto@na.infn.it;

Tel.: +39-081-676-160.

Academic Editor: Michael S. Breen

Received: 14 October 2015 / Accepted: 18 November 2015 / Published: 23 November 2015

\begin{abstract}
Indoor radon concentrations were measured in dwellings of the Puglia region in Southern Italy using LR-115 passive detectors. The results show that the radon concentrations varied from $15 \pm 2$ to $2166 \pm 133 \mathrm{~Bq} / \mathrm{m}^{3}$ with a geometric mean of $114 \mathrm{~Bq} / \mathrm{m}^{3}$ and a geometric standard deviation of 2.3. An analysis on the factors affecting radon concentration such as age of the dwellings, floors, and stories, was performed. The mean effective dose to inhabitants has been calculated and found to be $8.2 \mathrm{mSv} / \mathrm{y}$. Finally, for estimation of cancer risks, the lifetime risk and lung cancer cases per years per million have been calculated.
\end{abstract}

Keywords: radon indoor; LR-115 detectors; effective dose; Puglia-South Italy

\section{Introduction}

${ }^{222} \mathrm{Ra}$ and its progeny contribute more than half of human exposure from natural sources [1-3]. It is generated in rocks and soil by alpha decay of ${ }^{226} \mathrm{Ra}$ and for this reason it is present on the entire Earth's crust, although in varying quantities depending on the geology. After emission from the soil, radon can 
penetrate through cracks in walls and foundations inside homes where it can accumulate to harmful levels. Here, it decays and among its progenies, its short half-life alpha emitting daughters ${ }^{218}$ Po and ${ }^{214} \mathrm{Po}$ contribute most to the dose. Being electrically charged, they can attach to dust or smoke particles in indoor air. During the breathing process, they can reach the bronchial tissue and there they decay emitting radioactive alpha particles capable of damaging the pulmonary epithelium and thereby causing lung cancer. UNSCEAR estimates an average annual effective dose to general population of $1.15 \mathrm{mSv} / \mathrm{y}$ attributable to inhalation of radon and its progenies. For this reason and also considering that people spend $80 \%$ of the time at home, many investigations of domestic radon exposure have been stimulated worldwide. In 2009, on the basis of recent epidemiological studies on both mine and dwelling exposures [4-6], the International Commission on Radiological Protection (ICRP 115) [7] has recommended a detriment-adjusted nominal risk coefficient for a population of all ages of $8 \times 10^{-10}$ per Bq h $\cdot \mathrm{m}^{-3}$ for exposure to ${ }^{222} \mathrm{Ra}$ gas in equilibrium with its progeny (i.e., $5 \times 10^{-4} \mathrm{WLM}^{-1}$ ). Moreover, a recent epidemiological study stated that indoor radon exposure might increase lung cancer risk in never-smokers [8]. It is well know that radon concentrations in homes depends on a number of parameters such as building materials, geology, living environment, climate and so on [9-12]. This also produces a large variability of concentrations of indoor radon on a small scale, to the point that rooms in buildings very close to each other or even in the same building may present very different radon concentrations. In Italy, only one national survey has been carried out that investigated the radon concentrations in dwellings in the early 1990s [13]. Subsequently, other studies have been performed on a local scale with different methods of measurement to determine the radon concentration in homes and workplaces in various Italian regions [14-20]. In this work we report the results of a radon survey conducted in 2013-2014 in 311 dwellings on the Peninsula Salentina of the Puglia region, in Southern Italy. This study area is located in the southern region of Puglia, between the Ionian Sea to the west and the Adriatic Sea to the east. Geologically, the area presents a training Cretaceous carbonate with lithological levels that consist of pure limestone and compact, sometimes slightly dolomite or limestone marl. The South Puglia region, although it can be considered as a low radon risk zone, presents important local anomalies that could be attributed to the presence of terra rossa that is the main source of ${ }^{222} \mathrm{Rn}$ in the groundwater [21]. Moreover, Taroni et al. [22] showed that in the karst area of South Puglia the potential radon risk increased with the degree of alteration of subsoil structure; in particular in the zones characterized by high fracturing and big permeability, the range of radon in soil was high, from $400 \mathrm{~Bq} / \mathrm{m}^{3}$ to over the $60 \mathrm{kBq} / \mathrm{m}^{3}$.

The municipalities involved in the survey were 16 (Sava, Cellino San Marco, Novoli, Ostuni, campi Salentina, Lecce, Trepuzzi, Sannicola, San Cesario, Copertino, Matino, Galatina, Racale, Carmiano, Specchia) and homes were selected in each of them. All data on measurement sites are reported in Figure 1 and on an interactive Google map where it is possible to see the data of every single measurement [23]. 


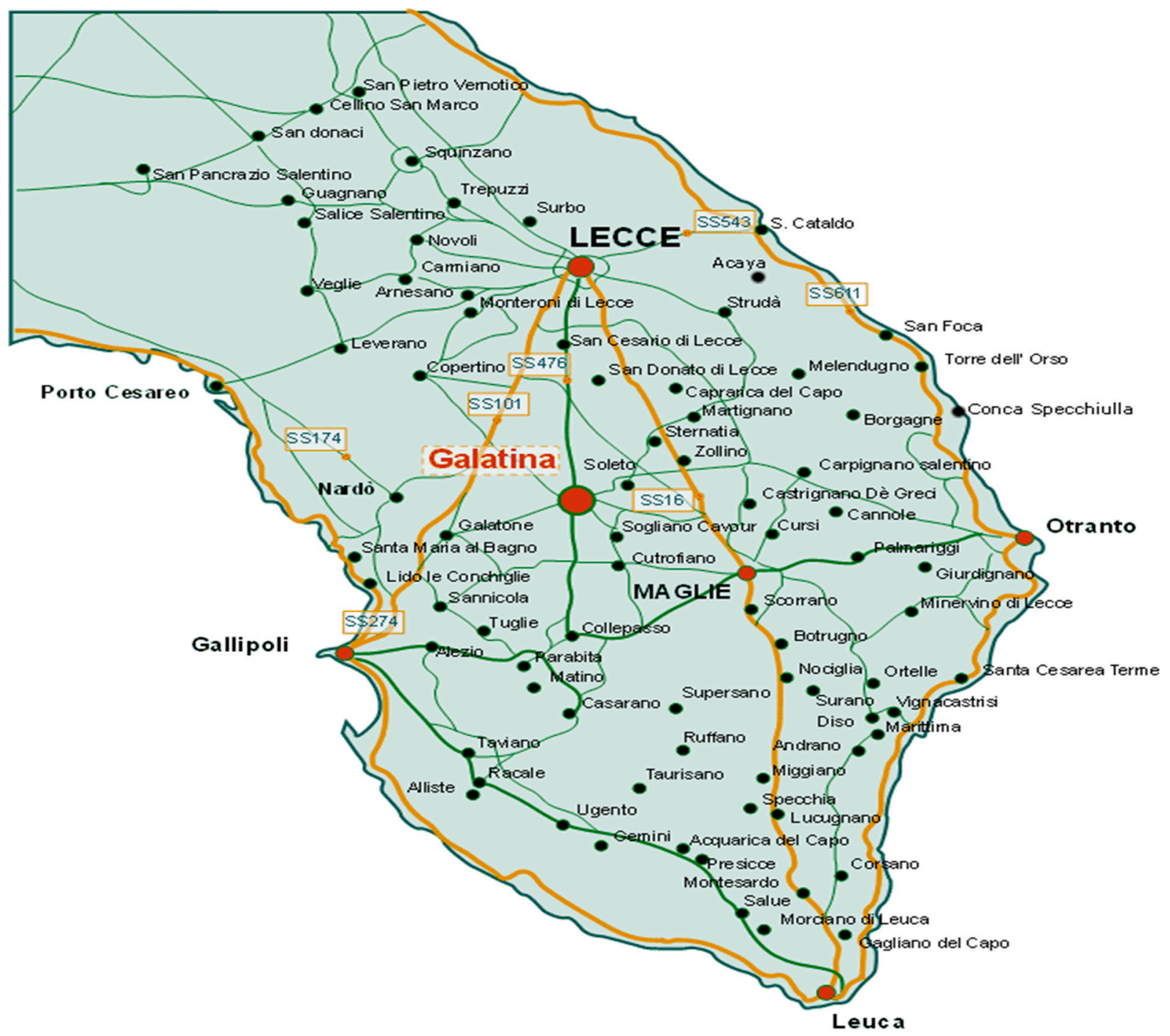

Figure 1. Map of Southern Puglia showing the area surveyed during the present investigation.

\section{Materials and Methods}

\subsection{Radon Measurements}

In September 2013 about 350 families were invited to participate in the indoor radon concentration survey. Each participant received a detector with instructions for its placement and a questionnaire concerning information about the main characteristics of their dwelling such as year of construction, main building materials, type and floor of the monitored room, etc. Unfortunately, due to mishandling by participants, 39 detectors were lost. The indoor radon concentration measurements were conducted using passive radon detectors, each equipped with a pair of LR-115 solid-state nuclear track detectors (SSNTD) provided by Dosirad (Pierrelatte, France). In each dwelling, the detectors was exposed in the rooms were the inhabitants spent the most of their time, generally the living room and bedroom, for six months. After exposure all detectors were chemically etched using a solution of $2.5 \mathrm{~N} \mathrm{NaOH}$ at $60{ }^{\circ} \mathrm{C}$ for $110 \mathrm{~min}$. For LR-115 detectors, the number of tracks increases linearly as the residual thickness decreases. In this study the residual thickness was measured with an optical method. The image of the detector was acquired by means of a scanner with double lighting and its mean brightness in the gray 
scale was determined using the image processing software Image (Image Processing and Analysis in Java, version 1.46r, National Institutes of Health, (Bethesda, MD, USA). Using a previously determined calibration curve, the brightness was then converted into residual thickness. The automatic counting of tracks was also performed using the ImageJ software- The background track density was estimated to be 10 tracks $/ \mathrm{cm}^{2}$ and it was determined counting the tracks of unexposed LR-115. Finally, the radon concentration was calculated using the Equation:

$$
C_{R n}=\frac{N}{E \times T}
$$

where $N$ is the track density corrected by background track density and normalized to the nominal thickness of $6.5 \mu \mathrm{m}, E$ is the efficiency and $T$ is the exposure time.

\subsection{Statistical Analysis}

The geometric mean was used to describe the central tendency of the radon measurements because their distribution was skewed. No seasonal adjustment was applied to the radon concentration data. The normality of log-transformed data was tested by Shapiro-Wilk, and the homogeneity of variance was tested by Bartlett's test. The comparison between two groups was performed with the non-parametric Mann-Whitney test for the log-transformed data. The comparisons between multiple groups were performed by non-parametric Kruskal-Wallis test. All statistical analyses were performed using the Stata software (Stata Corp., College Station, TX, USA).

\section{Results and Discussion}

\subsection{Radon Measurements}

The frequency distribution of the radon concentrations measured in 311 dwellings is shown in Figure 2. Although some authors [24-26] report that generally radon concentrations follow a log-normal distribution, the measured radon concentrations show an approximately log-normal distribution, although Shapiro-Wilk test failed to assess normality $(p<0.001)$. The reason for the lack of the log-normality could to be due to the great structural diversity of the geology of the sites and the variability of the types of housing. The minimum and maximum concentration were found to be $15 \pm 2 \mathrm{~Bq} / \mathrm{m}^{3}$ and $2166 \pm 133 \mathrm{~Bq} / \mathrm{m}^{3}$, respectively, with an geometric mean of $114 \mathrm{~Bq} / \mathrm{m}^{3}$, geometric standard deviation of 2.3 and the median value is $104 \mathrm{~Bq} / \mathrm{m}^{3}$. Overall, $74 \%$ of the dwellings presented radon concentrations lower than $200 \mathrm{~Bq} / \mathrm{m}^{3}, 9 \%$ had radon concentrations between 200 and $300 \mathrm{~Bq} / \mathrm{m}^{3}$, and the other $17 \%$ had values greater than $300 \mathrm{~Bq} / \mathrm{m}^{3}$. 


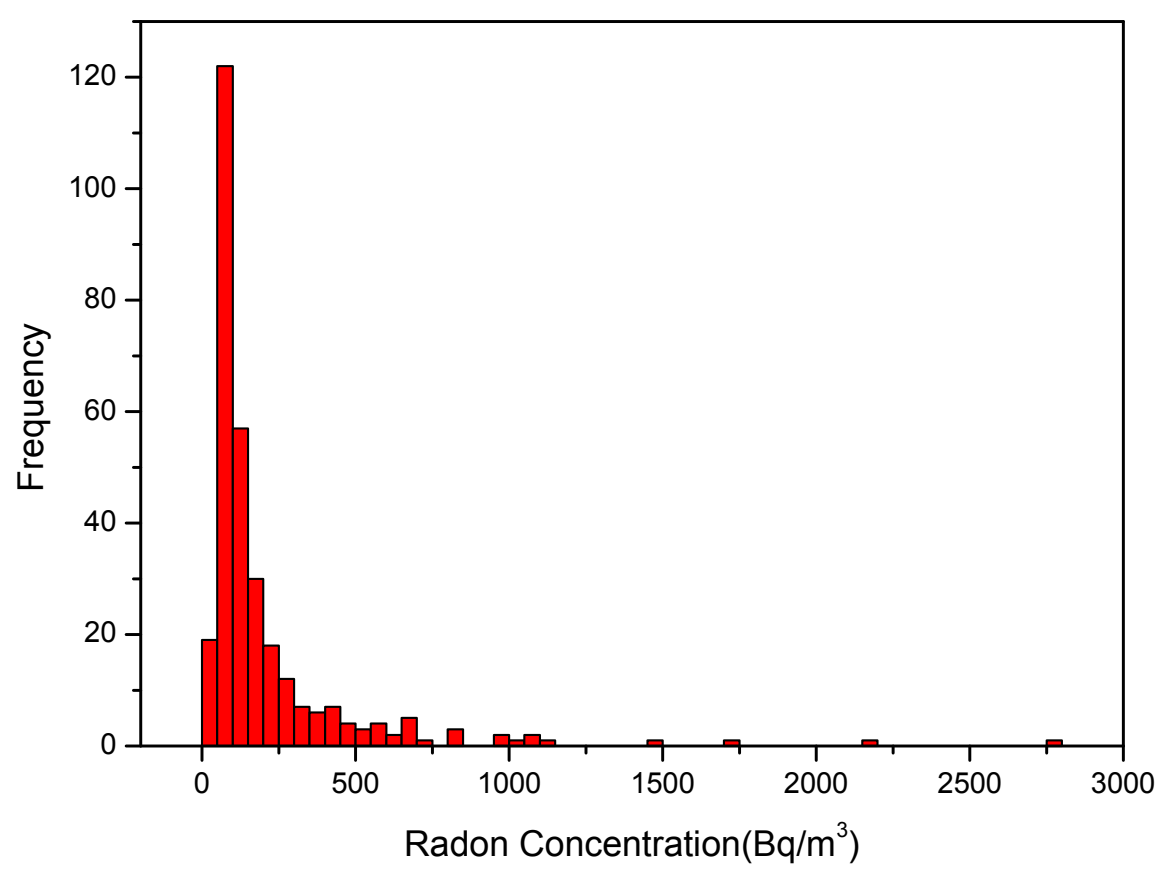

Figure 2. Frequency distribution of indoor radon concentrations in Peninsula Salentina dwellings.

Overall, $65 \%$ of the monitored dwellings were single-family houses, while $35 \%$ were multi-storey buildings. Using the Mann-Whitney test, a significant statistical difference $(p<0.05)$ was found between median of concentrations measured in the two building types, was observed in Figure 3. This result is in agreement with a study by Barros-Dios et al. [27] who observed that the radon concentrations declined with the number of the stories of a building.

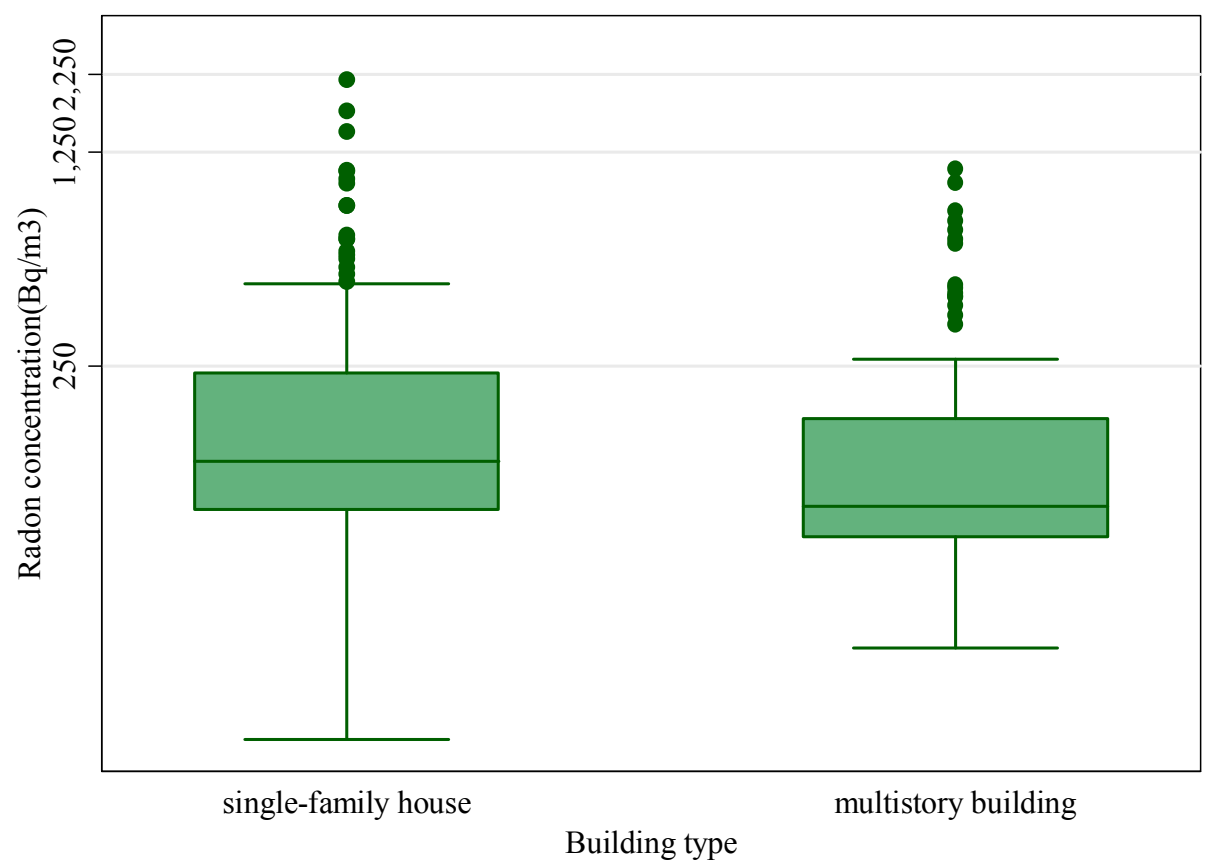

Figure 3. Relationship between radon concentrations and building types. 
In $64 \%$ of the homes the detector was placed in the bedrooms, and a statistical significantly difference between the radon concentrations measured in the living room and bedroom was found $(p<0.05)$, with Figure 4 showing that the radon concentrations measured in the bedrooms are higher than those measured in living rooms. This difference could be attributed to minor opening of the windows during the night that contributes to increased indoor radon concentrations in the bedrooms. The finding of this study is in good agreement with the results from other authors [10,28] that found higher radon concentrations in bedrooms than in living rooms.

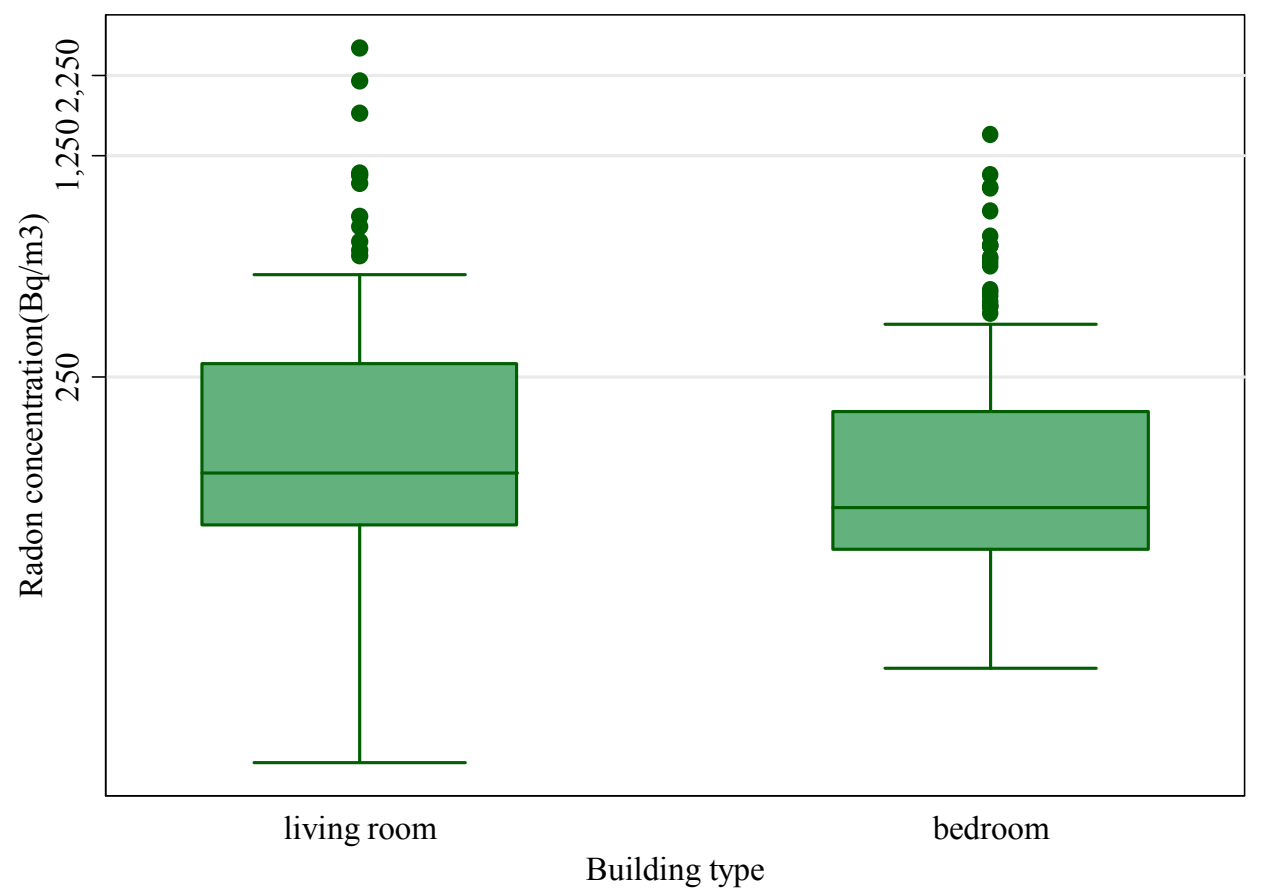

Figure 4. Relationship between radon concentrations and room types.

To evaluate the effect of the age of buildings on radon concentration, the houses were grouped in three categories: (i) built before of 1919; (ii) between 1919 and 1960 and (iii) after 1960 (Figure 5). The Kruskal-Wallis test showed that there is a significant difference $(p<0.05)$ in radon concentrations according to age of the dwellings. In particular, as shown in Figure 5 the median radon concentration is significantly higher for older houses compared with those built after 1960. Higher values reported for older houses could be explained by the fact that the ventilation rate in older houses is less than the new ones because they generally have smaller or fewer windows. Also older buildings have greater structural deterioration and poor ground insulation causing higher radon concentrations. Our results are consistent to that of other studies [27,29] that observed a statistically significant relationship between radon concentrations and dwelling age. 


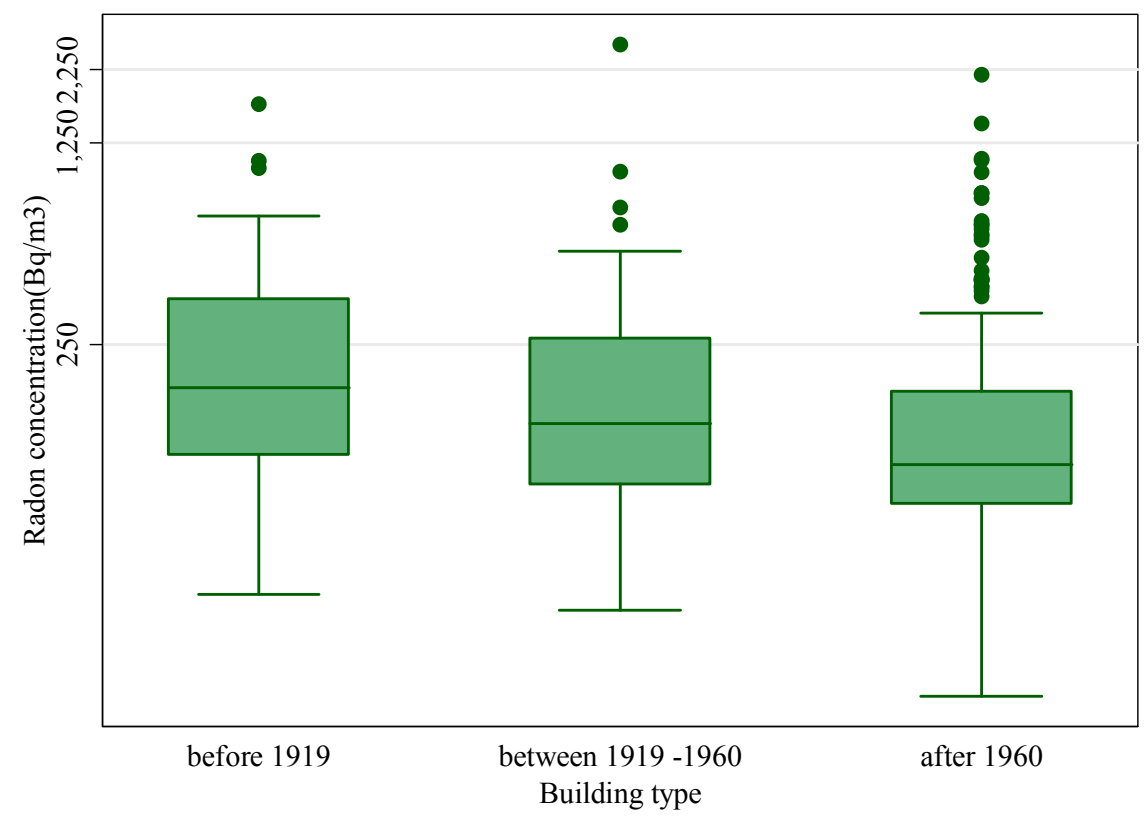

Figure 5. Relationship between radon concentrations and building age.

The statistical analysis showed that radon concentrations are significantly higher underground and at ground level compared with those of first and second floors $(p<0.01)$, as can be seen in Figure 6 . This finding could be attributed to proximity of the underground and ground levels to the soil that represents the main source of indoor radon and also due to higher radon accumulation on lower floors. This dependence of the radon concentrations on floor level was observed also by other authors $[10,11,27]$.

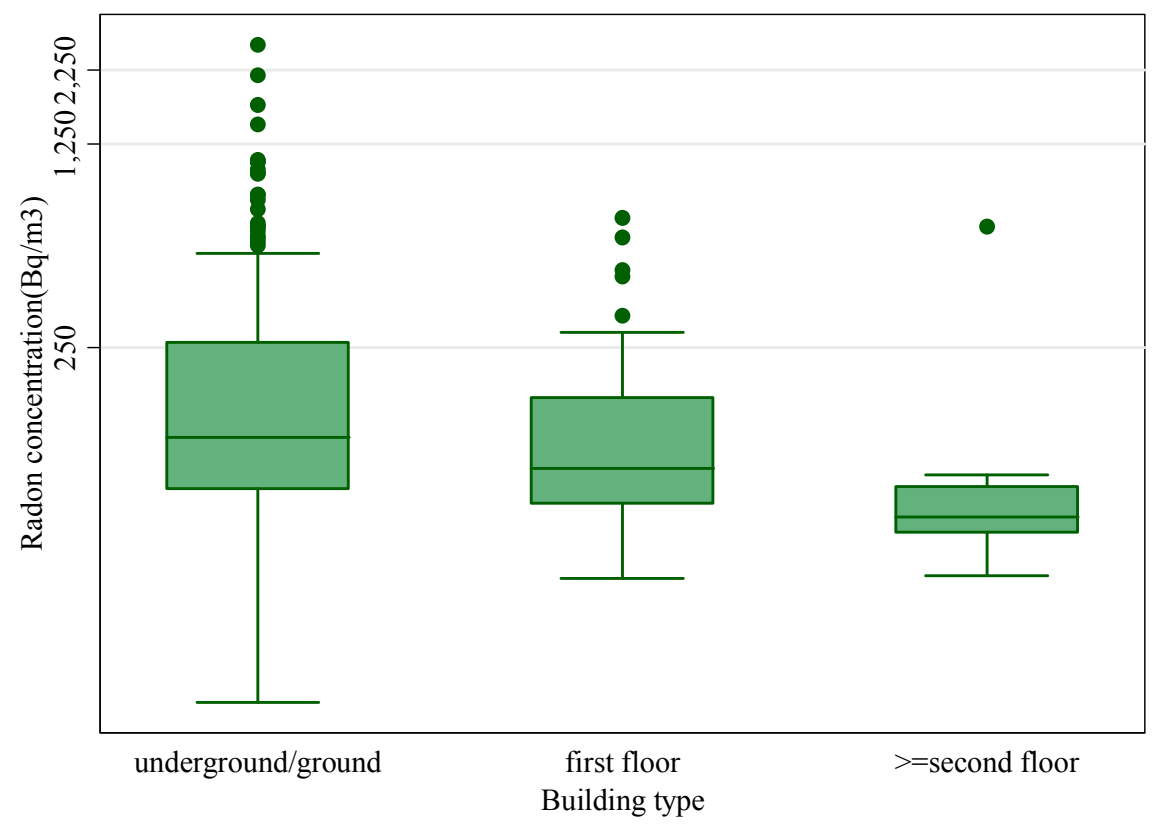

Figure 6. Relationship between radon concentrations and floor of the monitored rooms.

\subsection{Annual Effective Dose}

For the evaluation of the annual effective dose $\mathrm{H}$ to the inhabitants of the studied area due to the radon and its progeny, the UNSCEAR model was adopted, as reported in the following Equation: 


$$
\mathrm{H}(\mathrm{mSv} / \mathrm{y})=\mathrm{C} \times \mathrm{F} \times \mathrm{O} \times \mathrm{T} \times \mathrm{D}
$$

where $\mathrm{C}$ stands for the average radon concentration equal to $209 \mathrm{~Bq} / \mathrm{m}^{3}, \mathrm{~F}$ is the equilibrium factor for indoor that is set as $0.4, \mathrm{O}$ is the occupancy factor taken as $0.8, \mathrm{~T}$ is time in hours in a year $(8760 \mathrm{~h} / \mathrm{y})$ and $\mathrm{D}$ is the dose conversion factor, $1.4 \times 10^{-8} \mathrm{~Sv}$ per $\mathrm{Bq} / \mathrm{m}^{3} \mathrm{~h}$. The dose conversion coefficient reported in Equation (2) is obtained by equating the lung cancer risk of $8 \times 10^{-10} \mathrm{per} \mathrm{Bq} / \mathrm{m}^{3} \mathrm{~h}$ with total detriment for general population reported in ICRP 103 [29] that is $5.7 \times 10^{-2} \cdot \mathrm{Sv}^{-1}$. The mean annual effective dose was found to be $8.2 \mathrm{mSv} / \mathrm{y}$.

Excess life time cancer risk (ELCR) was estimated using the following Equation:

$$
\mathrm{ELCR}=\mathrm{H} \times \mathrm{DL} \times \mathrm{RF}
$$

where $\mathrm{H}$ is the mean effective dose, $\mathrm{DL}$ is the average duration of life estimated to a 70 years and RF is the fatal cancer risk per Sievert $\left(5.5 \times 10^{-2} \mathrm{~Sv}^{-1}\right)$ recommended by ICRP 103 . The mean excess lung cancer risk in the area was $3.1 \%$. Finally, using the conversion ion factor for cancer cases per year per million per person of ICRP 50 [30] of $18 \times 10^{-6} \mathrm{mSv}^{-1} \cdot \mathrm{y}$, the radon-induced lung cancer risk was found to be 147.6 per million persons.

\section{Conclusions}

In this study, the results of a radon survey carried out in set of Peninsula Salentina (Southern Italy) dwellings are reported. Radon levels present a geometric mean of $114 \mathrm{~Bq} / \mathrm{m}^{3}$ with a geometric standard deviation of 2.3. The findings show a statically significant correlation between indoor radon concentrations and some building characteristics such as floor level, age of the dwelling and number of stories. The estimated annual effective dose in the studied area was found to be $8.2 \mathrm{mSv} / \mathrm{y}$. The radoninduced lung cancer risk presents a value of 147.6 per million persons.

\section{Author Contributions}

Maria Quarto and Mariagabriella Pugliese planned the survey, contributed in implement and preparing and results interpretation. Giuseppe La Verde and Filomena Loffredo contributed to the logistics and radon measurements, including the etching of the detectors and analysis of images. Maria Quarto wrote the paper and Vincenzo Roca corrected the proof. All authors read and approved the final manuscript.

\section{Conflicts of Interest}

The authors declare no conflict of interest.

\section{References}

1. United Nations Scientific Committee on the Effects of Atomic Radiation (UNSCEAR). Available online: http://www.unscear.org/unscear/en/publications/2000_1.html (accessed on 14 October 2015).

2. The World Health Organization. WHO Hand Book on Indoor Radon; WHO: Geneva, Switzerland, 2009. 
3. Rani, A.; Singh, S.; Duggal, V. Indoor radon measurements in the dwellings of Punjab and Himachal Pradesh, India. Radiat. Prot. Dosim. 2013, 156, 118-124.

4. Lubin, J.H.; Wang, Z.Y.; Boice, J.D., Jr.; Xu, Z.Y.; Blot, W.J.; De Wang, L.; Kleinerman, R.A. Risk of lung cancer and residential radon in China: Pooled results of two studies. Int. J. Cancer 2004, 109, 132-137.

5. Darby, S.; Hill, D.; Auvinen, A.; Barros-Dios, J.M.; Baysson, H.; Bochicchio, F.; Deo, H.; Falk, R.; Forastiere, F.; Hakama, M.; et al. Radon in homes and lung cancer risk: Collaborative analysis of individual data from 13 European case-control studies. Br. Med. J. 2005, 330, 223-226.

6. Krewski, D.; Lubin, J.H.; Zielinski, J.M.; Alavanja, M.; Catalan, V.S.; Field, R.W.; Klotz, J.B.; le Tourneau, E.G.; Lynch, C.F.; Lyon, J.L.; et al. A combined analysis of North American case-control studies of residential radon and lung cancer. J. Toxicol. Environ. Health A 2006, 69, 533-597.

7. Lung Cancer Risk from Radon and Progeny and Statement on Radon. ICRP Publication 115. Available online: http://rpd.oxfordjournals.org/content/151/1/199.short (accessed on 14 October 2015).

8. Torres-Dura, M.; Ruano-Ravina, A.; Parente-Lamelas, I.; Leiro-Fernandez, V.; Abal-Arca, J.; Montero-Martinez, C.; Pena-Alvarez, C.; Gonzalez-Barcala, F.J.; Castro-Anon, O.; Golpe-Gomez, A.; et al. Lung cancer in never-smokers: A case-control study in a radon prone area Galicia, Spain. Eur. Respir. J. 2014, 44, 994-1001.

9. Brauner, E.V.; Rasmussen, T.V.; Gunnarsen, L. Variation in residential radon levels in new Danish homes. Indoor Air 2013, 23, 311-317.

10. Cucos, A.; Cosma, C.; Dicu, T.; Begy, R.; Moldovan, M.; Papp, B.; Nita, D.; Burghele, B.; Saiz, C. Thorough investigations on indoor radon in Baita radon-prone area (Romania). Sci. Total Environ. 2012, 432, 78-83.

11. Kropat, G.; Bochud, F.; Jaboyedoff, M.; Laedermann, J.-P.; Murith, C., Palacios, M.; Baechler, S. Major influencing factors of indoor radon concentrations in Switzerland. J. Environ. Radioact. 2014, 129, 7-22.

12. Nikolopoulos, D.; Kottou, S.; Louizi, A.; Petraki, E.; Vogiannis, E.; Yannakopoulos, P.H. Factors Affecting Indoor Radon Concentrations of Greek Dwellings through Multivariate Statistics-First Approach. Phys. Chem. Biophys. 2014, 4, 2-8.

13. Bochicchio, F.; Campos Venuti, G.; Nucciatelli, C.; Piermattei, S.; Risica, S.; Tommasino, L.; Torri, G. Results of the representative italian national survey on radon indoors. Health Phys. 1996, 71, 721-748.

14. Quarto, M.; Pugliese, M.; Loffredo, F.; Roca, V. Indoor radon concentrations measurements in some dwellings of the Penisula Sorrentina, South Italy. Radiat. Prot. Dosim. 2013, 156, 207-212.

15. Pugliese, M.; Quarto, M.; Loffredo, F.; Mazzella, A.; Roca, V. Indoor Radon Concentrations in Dwellings of Ischia Island. J. Environ. Protect. 2013, 4, 37-39.

16. Pugliese, M.; Quarto, M.; de Cicco, F.; de Sterlich, C.; Roca, V. Radon Exposure Assessment for Sewerage System's Workers in Naples, South Italy. Indoor Built Environ. 2013, 22, 575-579.

17. Catalano, R.; Immè, G.; Mangano, G.; Morelli, D.; Rosselli Tazzer, A. Indoor radon survey in Eastern Sicily. Radiat. Meas. 2012, 47, 105-110. 
18. Trevisi, R.; Caricato, A.; D’Alessandro, M.; Fernández, M.; Leonardi, F.; Luches, A.; Tonnarini, S.; Veschetti, M. A pilot study on natural radioactivity in schools of south-east Italy. Environ. Int. 2010, 36, 276-280.

19. Bochicchio, F.; Ampollini, M.; Antignani, S.; Bruni, B.; Quarto, M; Venoso, G. Results of the first 5 years of a study on year-to-year variations of radon concentration in Italian dwellings. Radiat. Meas. 2009, 44, 1064-1068.

20. Ciolini, R.; Mazed, D. Indoor radon concentration in geothermal areas of central Italy. J. Environ. Radioact. 2010, 101, 712-716.

21. Spizzico, M. Radium and radon content in the carbonate-rock aquifer of the southern Italian region of Apulia. Hydrogeol. J. 2005, 13, 493-505.

22. Taroni, M.; Bartolomei, P.; Esposito, M.; Vaccaro, C. High Radon concentration in the karst area of south Puglia, Italy. In Proceedings of the EGU General Assembly Conference, Vienna, Austria, 2-7 May 2010.

23. Measurements in Peninsula Salentina of Puglia Region. Available online: https://www.google.com/maps/d/viewer?hl=it\&authuser=0\&mid=zVcYa2ncyxGQ.kSBrDZr2cjn M (accessed on 14 October 2015).

24. Celebi, N.; Ataksor, B.; Taskin, H.; Albayrak Bingoldag, N. Indoor radon measurements in turkey dwellings. Radiat. Prot. Dosim. 2014, 11, doi:10.1093/rpd/ncu329.

25. Cosma, C.; Cucos, A.; Dicu, T. Preliminary results regarding the first map of residential radon in some regions in Romania. Radiat. Prot. Dosim. 2013, 2, doi:10.1093/rpd/nct015.

26. Epstein, L.; Koch, J.; Riemer, T.; Orion, I.; Haquin, G. Radon concentrations in different types of dwellings in Israel. Radiat. Prot. Dosim. 2014, 162, 605-608.

27. Barros-Dios, J.M.; Ruano-Ravina, A.; Gastelu-Iturri, J.; Figueras, A. Factors underlying residential radon concentration. Results from Galicia, Spain. Environ. Res. 2007, 103, 185-190.

28. Al-Khateeb, H.M.; Al-Qudah, A.A.; Alzoubi, F.Y.; Alqadi, M.K.; Aljarrah, K.M. Radon concentration and radon effective dose rate in dwellings of some villages in the district of Ajloun, Jordan. Appl. Radiat Isot. 2012, 70, 1579-1582.

29. The 2007 Recommendations of the International Commission on Radiological Protection. ICRP Publication 103. Available online: http://disciplinas.stoa.usp.br/pluginfile.php/235351/ mod_resource/content/1/ICRP_103_todo.pdf (accessed on 14 October 2015).

30. Lung Cancer Risk from Exposure to Radon Daughters. ICRP Publication 50. Available online: http://rpd.oxfordjournals.org/content/24/1-4/19.short (accessed on 14 October 2015).

(C) 2015 by the authors; licensee MDPI, Basel, Switzerland. This article is an open access article distributed under the terms and conditions of the Creative Commons Attribution license (http://creativecommons.org/licenses/by/4.0/). 